UDC 342.228

DOI 10.32755/sjcriminal.2020.01.103

Pekarchuk V. M.,

Doctor of Sciences (History), Professor, Professor of the Department of State and Law Theory and History, Constitutional Law, Academy of the State Penitentiary Service, Chernihiv, Ukraine ORCID: 0000-0002-7750-1474;

Chaika V. Yu.,

Officer of the 351-st academic group, Academy of the State Penitentiary Service, Chernihiv, Ukraine

\title{
PROBLEMS OF LEGAL LIABILITY FOR INFRINGEMENT ON STATE SYMBOLS
}

The concept of the category "legal liability" is revealed and its essential features are defined in the article.

It was found out that the current legislation provides only criminal liability: for public outrage to the State Flag of Ukraine, the State Coat of Arms of Ukraine or the National Anthem of Ukraine (Article 338 of the Criminal Code of Ukraine), as well as for illegal raising the State Flag of Ukraine on a river or sea vessel (Article 339 of the Criminal Code of Ukraine).

Criminal liability for public outrage to the State Flag of Ukraine, the State Coat of Arms of Ukraine or the National Anthem of Ukraine, as well as for illegal raising the State Flag of Ukraine on a river or sea vessel is analyzed.

The provision that Article 338 of the Criminal Code of Ukraine needs significant improvement and appropriate changes, as the authority of the Ukrainian state is undermined not only in case of infringement on the officially established flag and coat of arms of a foreign state is substantiated. In addition, it is advisable to introduce administrative liability for infringement on state symbols.

Key words: responsibility, legal liability, criminal liability, administrative liability, state symbols.

Target setting. A symbol, as one of the oldest forms of social communication, is a means of transmitting information. It is with the help of the symbol that the boundaries of a social group are determined. It is no coincidence that the sources of any nation and state always have a certain set of symbols, and the first thing that happens immediately after gaining independence is its consolidation in the attributes of state sovereignty - its state symbols. These include the state flag, state coat of arms and national anthem. The Constitution of Ukraine in Part 1 of Article 65 enshrined the obligation of all citizens of Ukraine to respect the state symbols, and it is stated in paragraph 4 of Part 2 of Article 92 that the procedure 
for the use and protection of state symbols is determined exclusively by the laws of Ukraine.

Until recently the current legislation provided only criminal liability: for public outrage to the State Flag of Ukraine, the State Coat of Arms of Ukraine or the National Anthem of Ukraine (Article 338 of the Criminal Code of Ukraine), as well as for illegal raising the State Flag of Ukraine on a river or sea vessel (Article 339 of the Criminal Code of Ukraine). In addition, due to the lack of a special law that would regulate the use of state symbols, it is almost impossible to classify illegal actions that fall under criminal liability as insulting them. All the above indicates the relevance of the research topic.

The state of elaboration of the problem. The problems of legal liability for on state symbols have been studied in the papers of a number of well-known domestic scholars. Among the papers on this topic we can note the papers of such authors as Yu.V. Baulin, V.A. Bortnyk, V.V. Karman, O.V. Kozachenko, V.I. Napyralska and others. Despite the considerable interest of legal theorists in this problem, its studying is still insufficient. The issues of legal liability for infringement on state symbols need in-depth study and analysis.

The purpose of the article is to study the problems of legal liability for infringement on state symbols, as well as to provide proposals for improving the current legislation regarding the regulation of liability for infringement on state symbols of Ukraine.

The statement of basic materials. Every citizen of Ukraine in accordance with Article 65 of the Constitution of Ukraine must respect its state symbols. Violation of this obligation is subjected to liability [1].

In order to disclose the issue of legal liability for infringement on state symbols, at the beginning we would like to mention that the general understanding of liability is a duty imposed on someone or assumed, to be responsible for a certain area of work, business, for someone's actions, deeds, words; seriousness, importance of the case, moment, etc. [2, p. 136].

Legal liability is a kind of social responsibility. It provides for the application to offenders (individuals and legal entities) of sanctions provided by the state in an enforcement procedure [3, p. 437].

Further we consider it to be appropriate to identify the substantive features of legal liability. 
Firstly, legal liability is an act of coercion with legal (certainty in the rule of law) and state-authoritative nature. The peculiarity of this type of liability is the state-legal nature of coercion of a person who committed the tort, as well as the regulation of legal liability (grounds, conditions, procedure, consequences, etc.) with legal norms. The essence of legal liability is laid down in the legal norms, which provide for certain requirements for lawful conduct and various consequences of a negative nature for failure to perform their duties [4, p. 28].

Secondly, legal coercion is manifested in the restriction or deprivation of certain rights or in the imposition of additional obligations on a person that would not have been applied if the person had behaved lawfully and had not committed an offense. In general theoretical jurisprudence, traditionally various forms of legal coercion, which is used while legal is liability implemented, are called deprivations, with the help of which the essence of legal liability is manifested.

Thirdly, the basis for applying legal liability is committing by a tort person of an illegal act (action or omission), which is recognized to be an offense, and for committing which the law provides for the application of the relevant type of legal liability. The absence in a person's actions of all the elements of an offense precludes the possibility of legal liability.

Fourthly, legal prosecution and its implementation must be carried out in the manner prescribed by law, in compliance with all the requirements of regulations. The process of realizing this type of responsibility is connected with the issuance by the state body of an act of applying the rule of law (law enforcement act), according to which the responsibility is put into practice, that means is realized. The special procedural form (procedure) of realizing legal responsibility is a guarantee of objective consideration of the fact of committing an offense and its proper assessment [4, p. 29].

Thus, legal liability should be understood as a measure provided by law of the state's response in the face of its bodies to comply with and execute legal norms.

It should be noted that the idea of protecting the dignity and authority of the state of Ukraine is reflected in the rule that provides for liability for public outrage to state symbols. That means public outrage to the State Flag of Ukraine, the State Coat of Arms of 
Ukraine or the National Anthem of Ukraine (Article 338 of the Criminal Code of Ukraine). These criminal acts are manifested in the mockery of the state symbols and the State Coat of Arms of Ukraine [5, p. 110-111]. Criminal liability is also provided for illegal raising the State Flag of Ukraine on a river or sea vessel (Article 339 of the Criminal Code of Ukraine) [6].

Regarding the occurrence of administrative liability for violations related to the improper use of state symbols, the Decree of the President of Ukraine dated February 9, 2001 № 79/2001 "Issues on the use of state symbols of Ukraine" defined the procedure for using state symbols of Ukraine for the period before their legislative settlement in order to educate citizens to respect these symbols, prevent their improper use, and establish administrative liability for violations related to the improper use of state symbols of Ukraine [7].

However, the current legislation does not provide for administrative liability for improper use of state symbols of Ukraine, so this situation slows down the implementation of European norms and rules in the field of state symbols of the Ukrainian state. It creates some legal conflicts in law enforcement agencies.

Thus, the current legislation provides only criminal liability: for public outrage to the State Flag of Ukraine, the State Coat of Arms of Ukraine or the National Anthem of Ukraine (Article 338 of the Criminal Code of Ukraine), as well as for illegal raising the State Flag of Ukraine on a river or sea vessel (Article 339 of the Criminal Code of Ukraine).

Ways of public outrage can be destructing or damaging the flag (coat of arms) by burning, breaking, painting, insulting inscriptions on the flag, bad caricature of the coat of arms or anthem, etc.

Public outrage to state symbols, provides for liability according to the Article 338 of the Criminal Code of Ukraine only if it was public (aimed at the public).

In the "Academic Explanatory Dictionary of the Ukrainian language" the term "public" is used in three meanings: 1) the one which takes place in the presence of the public, people; public; 2) intended for wide visiting, use; public; 3) (rarely) refers to the public [8, p. 383]. Thus, public outrage should be considered an outrage that took place in the presence of others and was directed at the public. In this case a guilty person can, for example, paint a flag 
both in the presence of other people, and without their presence, but with the subsequent removal of such flag on human eyes.

Part 2 of the Article 338 of the Criminal Code of Ukraine provides for criminal liability for outrage to the flag or coat of arms of a foreign state [6]. At the same time, the legislator recognized the official establishment of the flag or coat of arms of a foreign state as a condition for criminalizing such actions. Accordingly, unlike the flag and coat of arms of Ukraine, flags and coats of arms of foreign states, which have not been officially established or raised, are not the subject of a crime under Part 2 of the Article 338 of the Criminal Code of Ukraine.

Based on the fact that the flag (coat of arms) is considered to be officially installed or raised, which is raised (installed) on the territory of the embassy or consulate or in connection with the visit of a foreign delegation to its meeting place, etc., the destruction or damage of the flag (coat of arms), which has not been officially raised (installed), other public abuse of them or the flag (coat of arms) of an international organization is not criminally punishable [9, p. 175].

In addition, the outrage to the anthem of a foreign state in the national criminal law is not criminalized at all, while Part 1 of the Article 338 of the Criminal Code of Ukraine [6] establishes liability for similar actions against the National Anthem of Ukraine.

In our opinion, the considered norm of the criminal law needs significant improvement and introduction of corresponding changes as authority of the Ukrainian state is undermined not only in case of infringement on officially installed flag and coat of arms of a foreign state. For example, very often the flags foreign states are destroyed near embassy buildings in order to express public disagreement with the actions or decisions of the governments of the countries concerned. In this case, the intent is aimed at expressing disrespect for the state by outraging its official symbol. But this symbol is not officially installed therefore it is impossible to speak about structure of the crime provided by Part 2 of the Article 338 of the Criminal Code of Ukraine as well. This is a significant disadvantage of this rule, because in the latter case, Ukraine's authority in the world suffers due to the fact that the Ukrainian authorities allegedly failed by political and other means to prevent the demonstration of disrespect for the state symbols of a foreign state, and thus for itself. 
The sanction of the Article 338 of the Criminal Code of Ukraine provides for liability in the form of a fine of up to four thousand nontaxable minimum incomes, or arrest for up to 6 months, or imprisonment for up to 3 years. Public outrage to an officially installed or raised flag or coat of arms of a foreign state is also punishable by a fine of up to four thousand non-taxable minimums, or arrest for up to 6 months, or imprisonment for up to 2 years. Previously, liability for this crime was provided for in the Article 187-2 of the 1961 Criminal Code. Also, according to the Article 339 of the current Criminal Code of Ukraine, illegal raising of the State Flag on a river or sea vessel is punishable by a fine of up to fifty taxfree minimum incomes or arrest for up to six months [6].

However, due to the lack of a special law that would regulate the use of state symbols, it is almost impossible to classify illegal actions that fall under criminal liability as an outrage to them. At the same time, there are obvious examples of contempt for state symbols: tearing down the State Flag or the State Coat of Arms; their destructing or damaging; misusing symbols; outraging them, applying obscene inscriptions or drawings; distorting the text or music of the National Anthem; distributing its text with distortion of essence and meaning, etc. [10, p. 50].

Further we consider it appropriate to cite court verdicts on the initiation of a criminal case under the Article 338 of the Criminal Code of Ukraine.

Having analyzed the sentences set forth in the Unified State Register of Court Decisions under the Article 338 of the Criminal Code of Ukraine, it can be argued that in most cases the person acted intentionally, infringing on the state symbols of Ukraine. In addition, there are no cases in judicial practice in which it would be established that a person that committed an act in the form of outrage to state symbols of Ukraine acted negligently.

For example, in the verdict of the Southern City Court of Odessa region dated February 22, 2019 in case № 519/816/17 the court found out that on September 20, 2017 at 06 o'clock 07 minutes, PERSON_1, being in a state of intoxication, being on the territory of the recreation area, located at Odessa region, town of Yuzhne, T.H. Shevchenko street, in front of an apartment building № 7, 
acting intentionally, realizing the socially dangerous nature of his actions, realizing that he violates the order of use of state symbols of Ukraine, humiliating its authority and wishing to commit such actions, publicly outraged to the state symbol of Ukraine - the State Flag of Ukraine, which was expressed in the breaking of the raised State Flag of Ukraine and its damaging [11].

Another example of a criminal case under the Article 338 of the Criminal Code of Ukraine may serve the verdict of the Horodok District Court of Lviv region dated August 30, 2018 in the case № 441/1001/18. On May 22, 2018, at 22 o'clock 20 minutes, PERSON_1, being on the square between Haidamaky Square and Les Martovych street in the town of Horodok, Lviv region, near the monument "In memory of the victims of Stalin's repressions", on the grounds of obvious disrespect for Ukraine came to the place of installation of the State Flags of Ukraine on the above mentioned monument and using a cigarette lighter deliberately damaged two flags of Ukraine, which was expressed in intentionally arson the fabric of two flags. Continuing his criminal intent, he left them to burn down and partially burned them, thus committing public outrage to the State Flag of Ukraine [12].

Having analyzed the case law on the initiation of a criminal case under the Article 338 of the Criminal Code of Ukraine, it can be noted that the courts in their verdicts refer to the rules of substantive and procedural law and make a verdict on the basis of evidence submitted by the parties.

Taking into account the above situations described in the sentences, it can be noted that the subject of the crime acted intentionally in them. In addition, in most cases, the courts determine only the form of guilt in the sentences under Part 1 of the Article 338 of the Criminal Code of Ukraine - intentional, but do not determine the type of intent, possibly because it does not affect the qualification.

Conclusions. Thus, legal liability for infringement on state symbols is a measure of state influence on an offender, which is applied by the authorized state authorities for illegal acts, as a result of which state's authority and image were damaged. It should be noted that the current legislation provides only for criminal liability, and therefore, it would be appropriate to provide for administrative liability. The crime in the form 
of outrage to state symbols of Ukraine corresponds to the basic grounds and principles of criminalization, so the legislator quite rightly provided for criminal liability in the Articles 338, 339 of the Criminal Code of Ukraine, which is socially conditioned.

\section{References}

1. Verkhovna Rada of Ukraine (2010), Constitution of Ukraine, Law dated June 28, 1996 No. 254к/96-BP dated No. 72/1. Art. 2598.

2. Busel, V. T. (2003), Academic Explanatory Dictionary of the Ukrainian language, Kyiv, $1440 \mathrm{p}$.

3. Shemshuchenko, Yu. S. (1998), Law Encyclopedia: in 6 volumes, Kyiv, Vol. 1, 672 p.

4. Kozachenko, O. V. (2017), "Architectonics of criminal and legal influence: concepts, properties and system of criminal and legal measures", Bulletin of the Criminal Law Association of Ukraine, Issue 1 (8), pp. 22-40.

5. Bortnyk, V. A. (2004), Criminal and legal protection of person's honor and dignity: Ph.D. in Law thesis, $202 \mathrm{p}$.

6. Official Gazette of Ukraine (2001), Criminal Code of Ukraine: Law dated April 05, 2001, No. 2341-III. 2001, No. 21, Art. 920.

7. Official Gazette of Ukraine (2001), Issue on using state symbols of Ukraine, No. 79/2001, dated March 02, 2001, No. Art. 269.

8. Vynnyk, V. O., Zhaivoronok, V. V., Rodnina, L. O. and Chertoryzka, T. K. (1977), Academic Explanatory Dictionary of the Ukrainian language: in 11 volumes, Vol. 8, pp. 383.

9. Napyralska, V. I. (2013), "Problem issues of qualification of crimes according to the Art. 338 of the Criminal Code of Ukraine", State and Regions, Series: Law, No. 1, pp. 173-176.

10. Mishehlina, V. M. (2018), "Problems of legislative consolidation of the institute of state symbols in Ukraine: theoretical and constitutional-legal aspect", Evropsky politicky a pravni diskurz, Vol. 5, Issue 5, pp. 46-52.

11. Unified State Register of Court Decisions (2019), "Verdict of the Southern City Court of Odessa region dated February 22, 2019 in case № 519/816/17 (proceedings number: 1-кП/519/10/18)", available at: http://reyestr.court.gov.ua/Review/72368269 (accessed September 20, 2020).

12. Unified State Register of Court Decisions (2018), "Verdict of the Horodok District Court of Lviv region dated August 30, 2018 in the case № 441/1001/18”, available at: http://reyestr.court.gov.ua/Review/76168567 (accessed September 20, 2020). 
Пекарчук В. М.,

доктор історичних наук, професор, професор кафедри теорії та історії держави і права, конституційного права, Академія Державної пенітенціарної служби, м. Чернігів, Україна ORCID: 0000-0002-7750-1474;

Чайка В. Ю.,

слухач 351-ої навчальної групи, Академія Державної пенітенціарної служби, м. Чернігів, Україна ПРОБЛЕМИ ЮРИДИЧНОЇ ВІДПОВІДАЛЬНОСТІ ЗА ПОСЯГАННЯ НА ДЕРЖАВНІ СИМВОЛИ

У статті розкрито поняття категорії «юридична відповідальність» та визначено ї̈ сутнісні ознаки. Висвітлено загальне розуміння відповідальностіие обов'язок, покладений на когось або взятий на себе, відповідати за певну ділянку роботи, справу, за чиїсь дї, вчинки, слова; серйозність, важливість справи, моменту тощо. Встановлено, щуо різновидом сочіальної відповідальності є юридична відповідальність, яка передбачає застосування до правопорушників (фізичних та юридичних осіб) передбачених законодавством санкцій, щчо забезпечуються в примусовому порядку державою. Також досліджено поняття юридичної відповідальності, яка передбачає застосування до правопорушників (фізичних та юридичних осіб) передбачених законодавством санкиій, щуо забезпечуються в примусовому порядку державою.

Встановлено, щуо через відсутність спеціального закону, який би регулював порядок використання державних символів, практично неможливо кваліфікувати неправомірні діі, щуо підпадають під кримінальну відповідальність як наруга над ними.

3'ясовано, щуо чинним законодавством передбачена лише кримінальна відповідальність: за публічну наругу над Державним прапором Украйни, Державним гербом України або Державним гімном Украӥни (ст. 338 Кримінального кодексу Украӥни), а також за незаконне підняття Державного прапору Украӥни на річковому або морському судні (ст. 339 Кримінального кодексу Украӥни).

Аргументовано положення про те, щуо ст. 338 Кримінального кодексу України потребує суттєвого вдосконалення і внесення відповідних змін, оскільки авторитет української держави підривається не лише в разі посягання на офіційно встановлені прапор і герб іноземної держави. Крім того, дочільним є запровадження адміністративної відповідальності за посягання на державні символи.

Дійшли висновку, щзо кримінальне правопорушення у вигляді наруги над держсвними символами України відповідає основним підставам та принципам криміналізачії, тому законодавець ичілком справедливо передбачив за нього кримінальну відповідальність у ст.ст. 338, 339 КК Украӥни, яка є сочіально обумовленою.

Ключові слова: відповідальність, юридична відповідальність, кримінальна відповідальність, адміністративна відповідальність, державні символи. 